\title{
AMPLIFICATION OF THE fIgE GENE PROVIDES EVIDENCE FOR THE EXISTENCE OF A BRAZILIAN BORRELIOSIS
}

Elenice MANTOVANI, Roberta G. MARANGONI, Giancarla GAUDITANO, Virgínia L.N. BONOLDI \& Natalino H. YOSHINARI

\begin{abstract}
SUMMARY
Introduction: The symptoms of Brazilian borreliosis resemble the clinical manifestations of Lyme disease (LD). However, there are differences between the two in terms of epidemiological and laboratory findings. Primers usually employed to diagnose LD have failed to detect Borrelia strains in Brazil. Objective: We aimed to identify the Brazilian Borrelia using a conserved gene that synthesizes the flagellar hook $(f g E)$ of Borrelia burgdorferi sensu lato. Method: Three patients presenting with erythema migrans and positive epidemiological histories were recruited for the study. Blood samples were collected, and the DNA was extracted by commercial kits. Results: The gene $f l g E$ was amplified from DNA of all selected patients. Upon sequencing, these positive samples revealed 99\% homology to B. burgdorferi flgE. Conclusion: These results support the existence of borreliosis in Brazil. However, it is unclear whether this borreliosis is caused by a genetically modified B. burgdorferi sensu stricto or by a new species of Borrelia spp.
\end{abstract}

KEYWORDS: Lyme disease; Lyme disease-like; Spirochaetales.

\section{INTRODUCTION}

The Brazilian borreliosis resembles the classic Lyme disease (LD) of North America and Eurasia with characteristics of clinical features including erythema migrans (EM) skin lesions ${ }^{6,16}$ and osteoarticular, neurological and cardiac symptoms as the bacteria disseminates ${ }^{27,35,36}$.

However, the epidemiology and laboratory assays indicate that the causative agent inducing borreliosis in Brazil is different from commonly occurring borreliosis in North America. The ticks commonly associated with borreliosis to humans, Ixodes ricinus complex, have not been identified in regions of Brazil that possess a high incidence of borreliosis ${ }^{7,10}$. Borrelia burgdorferi, the LD etiological agent, was not present in BSK II medium cultures of patient blood samples ${ }^{36}$, ticks ${ }^{1,10}$ or reservoir animals in Brazil ${ }^{1}$. Moreover, specific serologic tests (ELISA and Western blotting), which identify antibodies to B. burgdorferi sensu lato of North American or European origins, have shown low sensitivity when applied to Brazilian patients' samples ${ }^{22,26}$.

Previous attempts to amplify genes specific to B. burgdorferi, including outer surface protein A (OspA) and genes for flagella filament (major flagellin FlaB, and minor flagellin FlaA), have failed in Brazilian samples. Ribosomal protein primers (16S rRNA) have also failed ${ }^{5,9}$. Other conserved genes that are necessary for Borrelia infection and survival in a variety of vertebrate and invertebrate hosts have also been investigated. The first targeted gene belonged to the cp32 plasmid group ${ }^{31}$, which was found to be preserved in the majority of B. burgdorferi strains. Due to strong homology with human DNA, gene products from cp32 could not be sequenced. Finally, genes encoded on $1 \mathrm{p} 25$ and $1 \mathrm{p} 28-1,{ }^{13,23}$ which are important for Borrelia virulence and infectivity, were investigated. The results were also negative.

The motility and morphology of B. burgdorferi is controlled by periplasmic flagella located between cell cylinder and outer membrane sheath. This structure is composed of a basal body, a hook and a filament (proteins FlaA and FlaB). Recently, SAL et al. have studied the importance of the flagella hook in B. burgdorferi biology by targeting the gene that encodes the hook structural protein $\mathrm{FlgE}^{25}$. Since previous Molecular Biology studies had failed to identify genes codifying flagella proteins, the aim of the present study was to test whether PCR targeting $f g E$ gene would be helpful to identify the etiological agent of Brazilian borreliosis.

\section{MATERIALS AND METHODS}

Patients: We selected three patients presenting with EM between November 2008 and October 2009. One patient was female and two were male, and the mean age was $47.3( \pm 28.2)$ years. They had a history of a tick bite and had visited high-risk areas in different regions of Brazil. All patients presented with flu-like symptoms, including fever, headache, myalgia, arthralgia, chills and fatigue (Table 1). All subjects fulfilled the Brazilian criteria for diagnosing borreliosis, as adopted by

Faculdade de Medicina da Universidade de São Paulo, Sao Paulo, SP, Brazil.

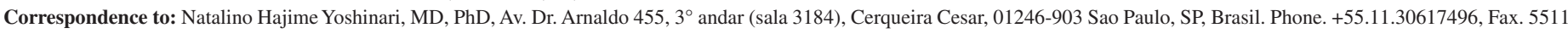
30617490. E-mail: yoshinari@lim17.fm.usp.br 
MANTOVANI, E.; MARANGONI, R.G.; GAUDITANO, G.; BONOLDI, V.L.N. \& YOSHINARI, N.H. - Amplification of the $f g E$ gene provides evidence for the existence of a Brazilian borreliosis. Rev. Inst. Med. Trop. Sao Paulo, 54(3): 153-7, 2012.

the Laboratório de Investigação em Reumatologia, Hospital das Clínicas, Faculdade de Medicina, University of São Paulo (LIM-17), the reference center in Brazil ${ }^{16,36}$.

Table 1

Epidemiological and clinical characteristics of the patients with Brazilian borreliosis

\begin{tabular}{lc}
\hline Features & Number $(\%)$ of patients \\
\hline Positive epidemiologic history & $3(100)$ \\
Tick bite history & $3(100)$ \\
Flu-like symptoms & $3(100)$ \\
Erythema migrans & $3(100)$ \\
Arthritis & $1(33.3)$ \\
Arthralgia & $3(100)$ \\
\hline
\end{tabular}

Two patients were in the acute stage (diagnosed within three months of disease onset) and one was in the latent stage (diagnosed more than three months after disease onset) of borreliosis. The patient who was in the latent disease stage had developed arthritis. Two (66.6\%) subjects had serological test results positive for B. burgdorferi G39/40 of North American origin, as determined by ELISA or WB according to Brazilian standardization ${ }^{18}$. The patient with negative serological test results was taking antibiotics at the time of blood sample collection (Table 2).

Thirty healthy individuals without a history of tick bite or recent travel to high-risk areas were included in the control group. Nineteen of the controls were female $(63.3 \%)$ and 11 were male $(36.7 \%)$. The mean age was $38.1( \pm 22)$ years.

This study was approved by the Ethics Committee in Research, CAPPesq of the Clinical Board of the School of Medicine - University of São Paulo, as stated in Protocol of Research number 0895/05. All patients and controls provided informed written consent.

\section{METHODS}

DNA was extracted using the QIAamp ${ }^{\circledast}$ DNA Blood Midi Kit (Qiagen $\mathrm{GmbH}$ ) from $2 \mathrm{~mL}$ of peripheral blood, following the manufacturer's instructions.

Based on the $\lg E$ gene, one primer pair was designed using the Primer3 online software ${ }^{24}$. These primers were as follows: $f g E 470 \mathrm{FW}$ (5'-CGCCTATTCTAACTTGACCCGAAT - 3') and flgE $470 \mathrm{Rev}$ (5'TTAGTGTTCTTGAGCTTAGAGTTG - 3').
Amplification was performed in a $50 \mu \mathrm{L}$ final volume reaction containing 5 pmoles of each primer, $10 \mathrm{mM}$ Tris- $\mathrm{HCl}, 1.5 \mathrm{mM} \mathrm{MgCl}$, $1.25 \mathrm{mM}$ dNTP and 1.5 U TaqDNA polymerase in DNAse/RNAse free $\mathrm{H}_{2} \mathrm{O}$ with $5 \mu \mathrm{L}$ of the DNA sample. DMSO $(1.5 \mu \mathrm{L})$ was added immediately before cycling ( $3 \%$ final concentration).

PCR cycle conditions consisted of an initial denaturation for $3 \mathrm{~min}$ at $95^{\circ} \mathrm{C}$, and 40 repetitive cycles of $45 \mathrm{~s}$ at $95^{\circ} \mathrm{C}, 45 \mathrm{~s}$ at $64^{\circ} \mathrm{C}, 45 \mathrm{~s}$ at $72^{\circ} \mathrm{C}$, followed by a final extension for $7 \mathrm{~min}$ at $72{ }^{\circ} \mathrm{C}$. Good laboratory practice to avoid contamination was always followed, and in every reaction, we included one negative control to check for possible contamination. $B$. garinii was used as a positive control in all reactions. PCR products were eletrophoresed through a $1.5 \%$ agarose gel, stained with SYBR Gold (Invitrogen) and examined by UV transillumination.

Positive samples were purified with the QIAEX $₫$ II Gel Extraction Kit (Qiagen $\mathrm{GmbH}$ ), and sequencing of genomic regions was performed with the BigDye Terminator Cycle Sequencing kit, version 3.1 (Applied Biosystems) and the ABI Prism 3730 DNA analyzer (Applied Biosystems). All sequences were examined for potential overlaps using the SeqManII program (DNAStar, Inc.). Prior to assembly, sequence ends were trimmed and primer sequences were removed manually. The sequences obtained were submitted for BLAST analysis to identify the sequences most closely related to the sample sequences ${ }^{2}$.

\section{RESULTS}

PCR targeting of the $f g E$ gene, which amplifies a fragment of $470 \mathrm{bp}$, yielded products in all patients evaluated (Fig. 1). The samples of the control group were not amplified by the primers used in this study.

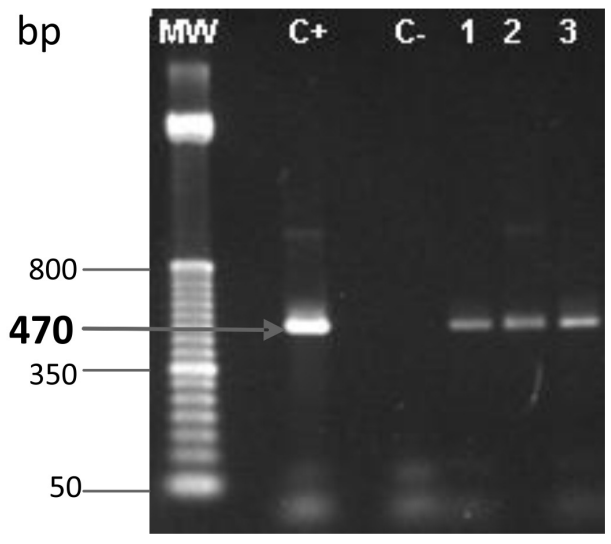

Fig. 1 - PCR flgE: MW = molecular weight $(50 \mathrm{bp}) ; \mathrm{C}+=$ B. garinii; $\mathrm{C}-\mathrm{=}$ control group; 1 , 2 and $3=$ Brazilian borreliosis patients.

Table 2

Demographic, treatment, and laboratory data of the patients with Brazilian borreliosis

\begin{tabular}{|c|c|c|c|c|c|}
\hline Patient & Age (years) & Symptoms onset (days) & Treatment (days) & Serology for B. burgdorferi & PCR $f l g E$ \\
\hline 1 & 67 & 11 & None & Positive & Positive \\
\hline 2 & 60 & 270 & None & Positive & Positive \\
\hline 3 & 15 & 30 & Tetracycline (7) & Negative & Positive \\
\hline
\end{tabular}


MANTOVANI, E.; MARANGONI, R.G.; GAUDITANO, G.; BONOLDI, V.L.N. \& YOSHINARI, N.H. - Amplification of the $f g E$ gene provides evidence for the existence of a Brazilian borreliosis. Rev. Inst. Med. Trop. Sao Paulo, 54(3): 153-7, 2012.

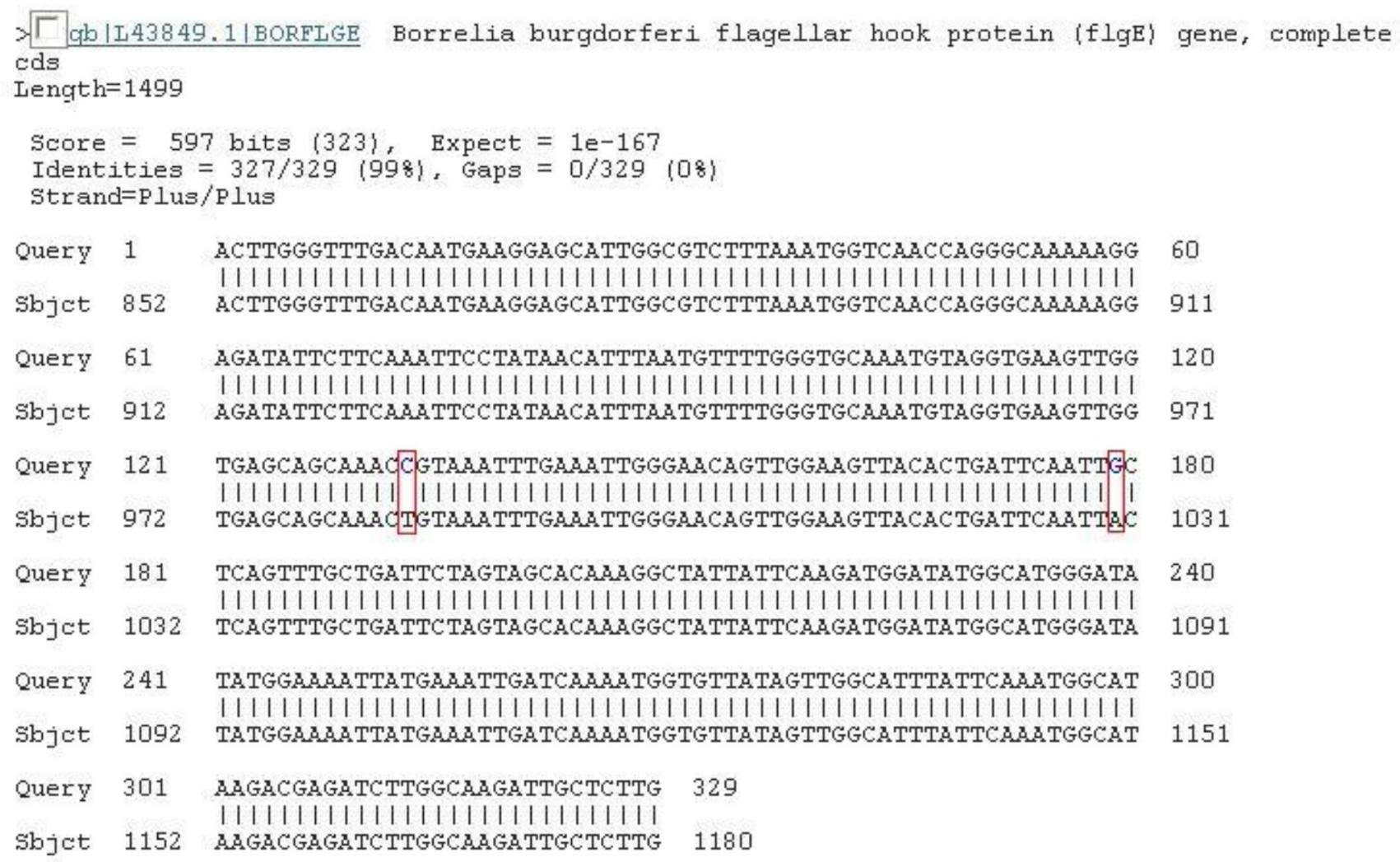

Fig. 2 - Alignment comparison of sequences generated from positive samples with the gene of Borrelia burgdorferi flagellar hook protein (flgE) (L43849) performed in BLAST. Base differences are outlined in red. All the three positive samples sequenced presented the same base difference when compared with Borrelia burgdorferi sensu stricto sequence.

Sequences disclosed an identity of $99 \%$ to the gene for B. burgdorferi $\operatorname{flgE}$ (L43849).

Partial sequences ( $f g E$ 470) of B. burgdorferi flgE generated in this study were $329 \mathrm{bp}$ in length, and they were submitted to GenBank (accession no. HM245929). Upon comparing our sequence to the fragment already deposited in GenBank (L43849), which corresponds to the B. burgdorferi $f g E$ gene, we could identify two different base substitutions (Fig. 2).

The sequence of the positive control (B. garinii) was compared with that of B. burgdorferi. Our positive control was $94 \%$ homologous to the gene for B. burgdorferi flagellar hook protein (L43849) and only $92 \%$ homologous to the sequence of the patients' samples. This eliminates the possibility that contamination had impacted the PCR.

\section{DISCUSSION}

Brazilian borreliosis has been investigated since $1989^{37}$. Understanding its etiology has been a priority for Brazilian researchers. Brazilian patients diagnosed with Borrelia infections characteristically had a history of exposure to ticks, showed frequent relapsing symptoms, had low serologic immune response to the etiological agent of LD (B. burgdorferi sensu lato antigens) and contained no Borrelia species in their blood that were able to be identified ex vivo. In the current study, we identified the $f g E$ gene in blood samples of patients diagnosed for Borrelia infection for the first time. Our study utilized a pair of primers derived from the conservative Borrelia gene $f g E$, which had not been previously tested to diagnose LD in the Northern Hemisphere.

The $f g E$ gene is identified in several species of Borrelia, including the etiological agents of relapsing fever (B. hermsii, B. duttonii, $B$. recurrentis). In this study, the comparison of our gene sequence in GenBank, showed that Brazilian spirochete had higher homology with microorganisms of B.burgdorferi sensu lato complex.

Several cases resembling LD symptoms have been reported in South America, Africa and Australia ${ }^{3,8,14,19,21,29}$. However, B. burgdorferi had never been cultured in BSK II medium or identified by molecular procedures in these continents. Recently, TALHARI et al. reported the occurrence of Lyme borreliosis in patients from the Brazilian Amazon Forest $^{32}$. They found spirochetes in skin biopsies of EM using specific immunohistochemistry and focus floating microscopy for B. burgdorferi. However, the authors failed to isolate and culture these microorganisms in BSK II medium. Also, nested PCRs targeting conserved genes were performed on DNA samples isolated from the biopsies and were negative. Therefore, molecular procedures targeting the $f g E$ gene may provide additional tools for understanding zoonosis presenting with a clinical spectrum resembling LD.

The $\mathrm{flg} E$ gene is formed of 1119 nucleotides and is responsible for the synthesis of the flagella hook structure ${ }^{15,23}$. The Brazilian spirochete 


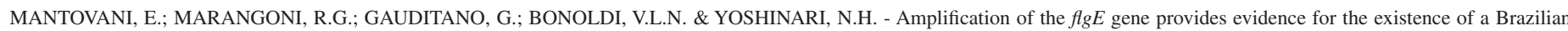
borreliosis. Rev. Inst. Med. Trop. Sao Paulo, 54(3): 153-7, 2012.

showed consistent differences in two nucleotides bases in comparison with $B$. burgdorferi sensu stricto. This distinctive feature may serve as a fingerprint for Brazilian Borrelia.

Importantly, DNA sequencing of positive samples from genus Rhipicephalus ticks and bovine peripheral blood demonstrated the same sequence pattern as seen in Brazilian patients. Their nucleotide alignment also showed different arrangement of two bases in comparison to B. burgdorferi sensu stricto sequence (unpublished data). Taken together, these findings reinforce the different epidemiology of Brazilian borreliosis from that described in LD.

In the current study, primers for $f l g E$ were tested on samples from a homogenous group of patients who possessed typical EM and positive epidemiological characteristics. Among the three studied subjects, two of them were at the acute disease stage and one was at the latent stage, complicated with arthritis. One of three serum samples showed negative serological results by ELISA and WB analysis, but this patient had received short courses of antibiotics with her EM rashes and had remained seronegative, whereas the other two patients had seroconverted. The ability of antibiotics to block seroconversion without eliminating infection is well documented ${ }^{11,17,20}$.

The two patients at the acute stage of disease presented with EM and flu-like symptoms after a tick bite episode. The patient in the latent stage was a 60-year-old man (patient 2) who was infected in the Amazon Forest. He presented with flu-like symptoms and EM at a tick bite site, and he was treated with $100 \mathrm{mg}$ doxycycline twice a day for 15 days. About eight months later, he presented with a relapsing episode of knee arthritis. At that time, serological tests performed for B. burgdorferi had positive results, and the PCR targeting the $f g E$ gene confirmed the diagnosis of borreliosis.

In Brazil, patients who receive inadequate treatment at the acute stage or are not diagnosed until the latent stage exhibit relapsing symptoms in approximately $75 \%$ of the cases ${ }^{27,35}$. Delay in diagnosis or misdiagnosis leads to improper treatment and an unfavorable outcome. Unfortunately, because Brazilian physicians are not used to identifying this emerging zoonosis, most of the cases are diagnosed at the latent stage of the disease.

The reasons for why there are differences between LD and Brazilian borreliosis are still unclear. Brazilian researchers speculate that the etiologic agent of Brazilian borreliosis could either be a different Borrelia species or a genetically modified B. burgdorferi sensu stricto ${ }^{38}$. It is common knowledge that borreliosis can be caused by different species of Borrelia. Recently, STANEK \& REITER ${ }^{30}$ reviewed all of the identified species/genospecies of Borrelia. According to the authors, 10 years after the discovery of spirochaetes as agents of LD in 1982 in the United States of America, three genomic species had diverged from the phenotypically heterogeneous strains of B. burgdorferi that were isolated in North America and Europe: B. afzelii, B. burgdorferi sensu stricto and B. garinii. In the 1990s, another seven genospecies were described, including species from Asia, North America and Europe. From 2000 to 2010, another eight species were delineated. Of these 18 genomic species, B. afzelii, B. burgdorferi and B. garinii are the confirmed agents of localized, disseminated and chronic manifestations of Lyme borreliosis. $B$. spielmanii has been detected in early skin disease, and $B$. bissettii and $B$. valaisiana have been detected in specimens from single cases of Lyme borreliosis. The clinical role of other Borrelia remains to be determined. Therefore, it is possible that a new "Brazilian species/ genospecies/variant" of Borrelia is circulating in Brazilian patients with localized, disseminated and chronic manifestations of borreliosis. In fact, the Brazilian geographic conditions and fauna biodiversity could have contributed to the development of a genetically modified spirochete, which is adapted to survive in the environmental conditions found in Brazil $^{12,28,33,34}$. This would explain the distinct attributes of Brazilian borreliosis, as well as the difficulty of culturing the microorganism in BSK II medium, the low sera reactivity to $B$. burgdorferi and the failure of PCR methods using primers targeting the gene of the outer membrane proteins and periplasmic flagella.

In conclusion, for the first time, we show that Brazilian borreliosis is caused by microorganisms possessing the flagellar hook gene $(f g E)$, reinforcing the presence of a Borrelia species in the country.

\section{RESUMO}

\section{Amplificação do gene $f l g E$ fornece evidência para a existência de uma borreliose brasileira}

Introdução: Os sintomas da borreliose brasileira se assemelham às manifestações clínicas da Doença de Lyme (DL), porém, existem diferenças epidemiológicas e laboratoriais entre essas enfermidades. Primers normalmente utilizados para diagnosticar a DL não conseguiram detectar cepas de borrelia no Brasil. Objetivo: O objetivo desse trabalho foi identificar a borrelia brasileira usando um gene conservado que sintetiza o gancho flagelar (flgE) da Borrelia burgdorferi sensu lato. Método: Três pacientes com eritema migratório e epidemiologia positiva foram recrutados para o estudo. Amostras de sangue foram coletadas, e o DNA foi extraído por kits comerciais. Resultados: O gene $\operatorname{fgE}$ foi amplificado a partir do DNA de todos os pacientes selecionados. Após o sequenciamento, essas amostras positivas revelaram homologia de $99 \%$ para B. burgdorferi. Conclusão: Estes resultados reforçam a existência de borreliose no Brasil. No entanto, não está claro se esta borreliose é causada por uma variante geneticamente modificada da $B$. burgdorferi sensu stricto ou por uma nova espécie de Borrelia spp.

\section{ACKNOWLEDGMENTS}

We would like to thank David Volkman for critical review of the manuscript. Additionally, we would like to thank Flavia R. R. Mangone and Fatima S. Pasini for technical support. This study was supported by a research grant from Fundação de Amparo à Pesquisa do Estado de São Paulo (FAPESP) grant $n^{\circ}$ 05/56166-8 and Federico Foundation (grant for Yoshinari).

\section{REFERENCES}

1. Abel IS, Marzagão G, Yoshinari NH, Schumaker TT. Borrelia-like spirochetes recovered from ticks and small mammals collected in the Atlantic Forest Reserve, Cotia county, State of São Paulo, Brazil. Mem Inst Oswaldo Cruz. 2000;95:621-4.

2. Altschul SF, Gish W, Miller W, Myers EW, Lipman DJ. Basic local alignment search tool. J Mol Biol. 1990;215:403-10.

3. Arocha-Sandoval F, Amesty-Valbuena A, Urbina M, Durango AI, Vargas-Montiel H. Detección de anticuerpos contra Borrelia burgdorferi en una muestra poblacional del Estado de Zulia. Invest Clin. 1994;35:91-104. 
MANTOVANI, E.; MARANGONI, R.G.; GAUDITANO, G.; BONOLDI, V.L.N. \& YOSHINARI, N.H. - Amplification of the $f g E$ gene provides evidence for the existence of a Brazilian borreliosis. Rev. Inst. Med. Trop. Sao Paulo, 54(3): 153-7, 2012.

4. Barbour AG, Hayes SF. Biology of Borrelia species. Microbiol Rev. 1986;50:381-400.

5. Barros PJL. Clinical and laboratory characterization of Lyme disease in Brazil, using immunological methods and polymerase chain reaction. [Dissertation]. São Paulo: University of São Paulo; 2000.

6. Barros PJL, Levy LH, Monteiro FG, Yoshinari NH. Lyme disease: cutaneous involvement and treatment of the initial phases. Rev Assoc Med Bras. 1993;39:170-2.

7. Barros-Battesti DM, Yoshinari NH, Bonoldi VLN, de Castro Gomes AC. Parasitism by Ixodes didelphidis and I. loricatus (Acari: Ixodidae) on small wild mammals from an Atlantic Forest in the State of Sao Paulo, Brazil. J Med Entomol. 2000;37:820-7.

8. Cestnick L. Lyme disease in Australia. Aust N Z J Public Health. 1998;22:524.

9. Costa IP, Bonoldi VLN, Yoshinari NH. Perfil clínico e laboratorial da doença de Lymesímile no Estado de Mato Grosso do Sul: análise de 16 pacientes. Braz J Rheumatol. 2001;41:142-50

10. Costa IP, Bonoldi VLN, Yoshinari NH. Search for Borrelia sp. in ticks collected from potential reservoirs in an urban forest reserve in the State of Mato Grosso do Sul, Brazil: a short report. Mem Inst Oswaldo Cruz. 2002;97:631-5

11. Dattwyler RJ, Volkman DJ, Luft BJ, Halperin JJ, Thomas J, Golightly MG. Seronegative Lyme disease. Dissociation of specific T- and B-lymphocyte responses to Borrelia burgdorferi. N Engl J Med. 1988; 319: 1441-6.

12. Derdáková M, Lencáková D. Association of genetic variability within the Borrelia burgdorferi sensu lato with the ecology, epidemiology of Lyme borreliosis in Europe. Ann Agric Environ Med. 2005;12:165-72.

13. Iyer R, Kalu O, Purser J, Norris S, Stevenson B, Schwartz I. Linear and circular plasmid content in Borrelia burgdorferi clinical isolates. Infect Immun. 2003;71:3699-706.

14. Jowi JO, Gathua SN. Lyme disease: report of two cases. East Afr Med J. 2005;82:267-9

15. Jwang B, Dewing P, Fikrig E, Flavell RA. The hook protein of Borrelia burgdorferi, encoded by the flgE gene, is serologically recognized in Lyme disease. Clin Diagn Lab Immunol. 1995;2:609-15.

16. Mantovani E, Costa IP, Gauditano G, Bonoldi VL, Higuchi ML, Yoshinari NH. Description of Lyme disease-like syndrome in Brazil. Is it a new tick borne disease or Lyme disease variation? Braz J Med Biol Res. 2007;40:443-56.

17. Mouritsen CL, Wittwer CT, Litwin CM, Yang L, Weis JJ, Martins TB, et al. Polymerase chain reaction detection of Lyme disease: correlation with clinical manifestations and serologic responses. Am J Clin Pathol. 1996;105:647-54.

18. Naka EN, Costa IP, Arão CAB, Soares CO, Yoshinari NH. Pesquisa de anticorpos Borrelia e anti-Babesia em soro de crianças com manifestações clínicas e epidemiológicas compatíveis com a doença de Lyme-símile no Estado de Mato Grosso do Sul. Rev Bras Reumatol. 2008;48:74-85.

19. Neira O, Cerda C, Alvarado MA, Palma S, Abumohor P, Wainstein E, et al. Lyme disease in Chile. Prevalence study in selected groups. Rev Med Chil. 1996;124:537-44.

20. Oksi J, Uksila J, Marjamaki M, Nikoskelainen J, Viljanen MK. Antibodies against whole sonicated Borrelia burgdorferi spirochetes, 41-kilodalton flagellin, and P39 protein in patients with PCR- or culture-proven late Lyme borreliosis. J Clin Microbiol. 1995;33:2260-4

21. Palacios R, Osorio LE, Giraldo LE, Torres AJ, Philipp MT, Ochoa MT. Positive IgG Western blot for Borrelia burgdorferi in Colombia. Mem Inst Oswaldo Cruz. 1999;94:499-503.
22. Pirana S, Yoshinari NH, Silveira AM, Bento RF, Bonoldi VLN. Serum reactivity for Borrelia burgdorferi, Borrelia afzellii and Borrelia garinii antigens in patients with peripheral facial paralysis in Brazil. Braz J Rheumatol. 2000;40:55-9.

23. Purser JE, Norris SJ. Correlation between plasmid content and infectivity in Borrelia burgdorferi. Proc Natl Acad Sci USA. 2000;97:13865-70.

24. Rozen S, Skaletsky HJ. Primer3 on the WWW for general users and for biologist programmers. Methods Mol Biol. 2000;132:365-86.

25. Sal MS, Li C, Motalab MA, Shibata S, Aizawa SI, Charon NW. Borrelia burgdorferi uniquely regulates its motility genes and has an intricate flagellar hook-basal body structure. J Bacteriol. 2008;190:1912-21.

26. Santos M, Ribeiro-Rodrigues R, Lobo R, Talhari S. Antibody reactivity to Borrelia burgdorferi sensu stricto antigens in patients from the Brazilian Amazon region with skin diseases not related to Lyme disease. Int J Dermatol. 2010;49:552-6.

27. Shinjo SK, Gauditano G, Marchiori PE, Bonoldi VLN, Costa IP, Mantovani E, et al Neurological manifestations in Baggio-Yoshinari Syndrome (Brazilian Lyme diseaselike syndrome). Braz J Rheumatol. 2009;49:492-505.

28. Skotarczak B. Adaptation factors of Borrelia for host and vector. Ann Agric Environ Med. 2009;16:1-8.

29. Stanchi NO, Balague LJ. Lyme disease: antibodies against Borrelia burgdorferi in farm workers in Argentina. Rev Saude Publica. 1993;27:305-7.

30. Stanek G, Reiter M. The expanding Lyme Borrelia complex-clinical significance of genomic species? Clin Microbiol Infect. 2011;17:487-93.

31. Stewart PE, Byram R, Grimm D, Tilly K, Rosa PA. The plasmids of Borrelia burgdorferi: essential genetic elements of a pathogen. Plasmid. 2005;53:1-13.

32. Talhari S, Santos MNS, Talhari C, de Lima Ferreira LC, Silva RM Jr, Zelger B, et al. Borrelia burgdorferi "sensu lato" in Brazil: occurrence confirmed by immunohistochemistry and focus floating microscopy. Acta Tropica. 2010;115:200-4

33. Tsao JI. Reviewing molecular adaptations of Lyme borreliosis spirochetes in the context of reproductive fitness in natural transmission cycles. Vet Res. 2009;40(2):36

34. Yang X, Goldberg MS, Popova TG, Schoeler GB, Wikel SK, Hagman KE, et al. Interdependence of environmental factors influencing reciprocal patterns of gene expression in virulent Borrelia burgdorferi. Mol Microbiol. 2000;37:1470-9.

35. Yoshinari NH, Barros PJL, Bonoldi VLN, Ishikawa M, Battesti DMB, Pirana S, et al Outline of Lyme borreliosis in Brazil. Rev Hosp Clin Fac Med S Paulo. 1997;52:111-7.

36. Yoshinari NH, Mantovani E, Bonoldi VL, Marangoni RG, Gauditano G. Brazilian Lymelike disease or Baggio-Yoshinari Syndrome: exotic and emerging Brazilian tick-borne zoonosis. Rev Assoc Med Bras. 2010;56:363-9.

37. Yoshinari NH, Steere AC, Cossermelli W. A review of Lyme disease. Rev Assoc Med Bras. 1989;35:34-8.

38. Yoshinari NH, Vasconcelos AS, Tiriba AC, Gauditano G, Mantovani E, Bonoldi VLN Report of unusual presence of latent microorganisms in animals: a risk to research and health of employees? Braz J Rheumatol. 2009;49:517-28.

Received: 2 August 2011

Accepted: 10 February 2012 


\section{Revista do Instituto de Medicina Tropical de São Paulo on line.}

Publications from 1987 to the present data are now available on:

http://www.scielo.br/rimtsp

PAST ISSUES 1959-1989 (PDF)

www.imt.usp.br/portal/

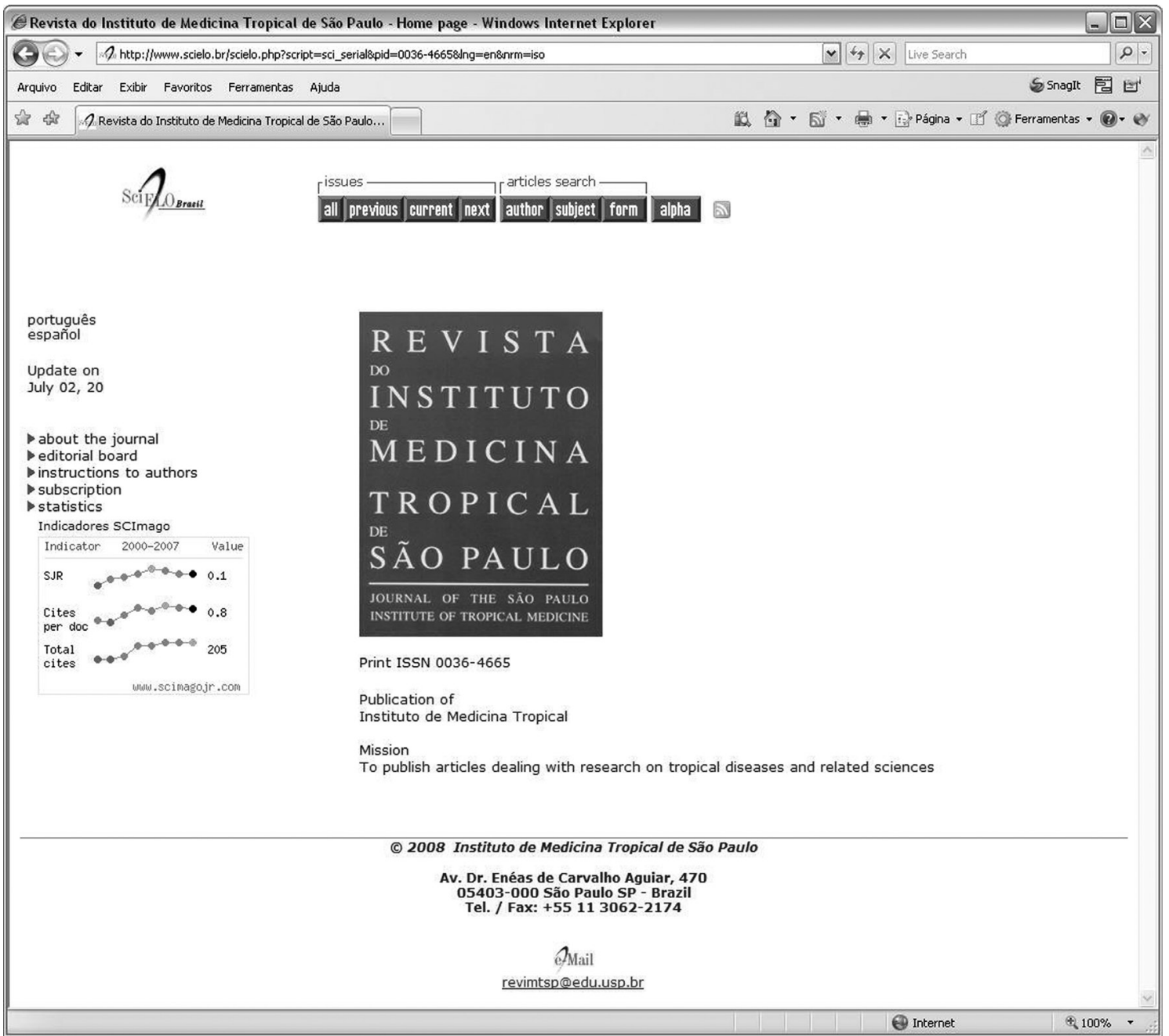

SciELO - The Scientific Electronic Library OnLine - SciELO is an electronic virtual covering a selected collection of Brazilian scientific journals.

The library is an integral part of a project being developed by FAPESP - Fundação de Amparo à Pesquisa do Estado de São Paulo, in partnership with BIREME - the Latin American and Caribbean Center on Health Sciences Information.

SciELO interface provides access to its serials collection via an alphabetic list of titles or a subject index or a search by word of serial titles, publisher names, city of publication and subject.

The interface also provides access to the full text of articles via author index or subject index or a search form on article elements such as author names, words from title, subject and words from full text.

FAPESP/BIREME Project on Scientific Electronic Publications Latin American and Caribbean Center on Health Sciences Information

Rua Botucatu 862 - 04023-901 São Paulo, SP - Brazil

Tel. (011) 5576-9863

scielo@bireme.br 